\title{
Co-Mo-Cr alloys for dentistry obtained by vacuum precise casting
}

\begin{abstract}
There are several biocompatible Co-Cr-Mo alloy compositions, as well as technological processes suitable for obtaining the tablet samples aimed to produce dental implants and orthodontic devices. Here presented Co-Cr-Mo alloy, besides its biocompatibility, corrosion resistance, and nickel absence, is favorable for its mechanical properties, such as hardness, tensile and fatigue strength.

The technology for raw materials preparation and manufacturing of a Co-Cr-Mo alloy for dental implants vacuum precise casting is presented here. Besides the technological process characteristics, there are the chemical analysis of raw materials, alloy obtaining guidelines and microstructure of as-cast samples.
\end{abstract}

Key words: Co-Cr-Mo alloy, dental implants, vacuum casting.

\section{INTRODUCTION}

Co-Cr-Mo alloys are being investigated to be used as dental implants, prosthesis parts - such as crowns, bridges and dentures, orthodontic devices and supporting material, for more than three decades because of their biocompatibility. A material that is planned for implantation into a biological media is considered biocompatible if it does not exhibit some undesired effects upon the living organism, and vice versa, if such a media do not affect the material itself. Biocompatibility of these alloys is enabled by oxide film formation, consisted of mostly $\mathrm{Cr}_{2} \mathrm{O}_{3}$, and slight amounts of cobalt and other metal oxides on the surface. These alloys are favored for applications where metal-to metal contact is envisaged, since they have superior wear-resistance properties comparing with biocompatible titanium alloys [1-3]. Besides the dental applications, they are used for hip or knee joint implants, or surgical prostheses, even for support structures of the heart valves [1].

The biocompatibility and mechanical properties, especially wear-resistance, are affected by microstructure and by thermal treatment of the material. Good mechanical properties of Co-Cr-Mo alloys are comparable to stainless steel. They depend on of phase's structure and precipitation of carbides, which homogeneous distribution can increase the hardness of these alloys [4-6]. The microstructure depends on the manufacturing process. There are reported technologies on Co-CrMo alloys produced in the form of casted or wrought material, or processed by powder-metalurgy. The aim is to obtain homogenous, fine-grained structure which has better corrosion resistance. Tensile and fatigue strength increases drastically as they are heat-treated [7-9].

Author's address: Institute for Technology of Nuclear and Other Mineral Raw Materials, Franchet d'Esperey Street 86, Belgrade, Serbia

Paper received: 13. 12. 2014.

Paper accepted: 21. 02. 2015.

\section{MATERIALS}

The used raw materials were of the following composition:

Cobalt: Electrolytic cobalt is the alloy base, contained the following impurities (in \%): Ni-0.002, Fe-0.002, Cu-0.001, S-0.003, the rest was cobalt. Chromium: Chromium was obtained through aluminothermic process and contained the following impurities (in \%): C-0.005, Si-0.05, S-0.04, P0.03, Al-0.07, Fe-0.7, Cu-0.1. Manganese: Electrolytic manganese, in a form of flakes, contained the following impurities (in \%): Si-0.01, Fe-0.07, S$0.05, \mathrm{~Pb}+\mathrm{Zn}+\mathrm{Mo}-0.02$, the rest was Mn. Molybdenum was obtained by a power metallurgy process and contained the following impurities (in \%): W-0.1, Fe0.07, Mn-0.002, Cr-0.007, C-0.009, Al0.002 . Silicon was obtained through electro-thermal reduction of quartz and was of the following composition (in \%): C-0.1, Mn-0.5, Ca-0.2, Ti-0.1, $\mathrm{Al}-1.0, \mathrm{P}-0.04, \mathrm{~S}-0.04$, the rest was silicon.

Cobalt, the basis of the alloy determines the main mechanical properties, such as hardness, toughness and strength. Chromium, another component of the alloy basis, provides for stability of colour and electrochemical stability by forming a continuous film of various oxides that prevent a further diffusion of metal atoms and their contact with oxygen. Molybdenum enables alloy to be resistant to halogens and their compound. Together with manganese and silver, it contributes to a fluidity of melted alloy. Due to its high elasticity modulus, it increases alloy elasticity. Manganese primary role is detoxification and cleaning of alloy during melting. It helps the activity of molybdenum in resistance towards halogens. Iron is inevitable component of an alloy, usually detected during analysis; it improves alloy processing, but decreases electrochemical stability. Silicon like manganese enables and detoxification and cleaning of alloy during melting process. Carbon protects 
metals from oxidation. Its content should be very precisely controlled, because it tends to form carbides with present metals and influences many important properties, such as elasticity, hardness or strength.

The starting raw materials were granulated to a size of $0.5-5 \mathrm{~mm}$. This enables the melting stability and obtaining homogenous alloy.

\section{THE EXPERIMENTAL PROCEDURE}

The alloy was produced in a vacuum induction furnace, which enables obtaining the alloys of defined chemical composition, prevented from oxidation. Melting and casting was conducted under the vacuum of 0.04 mbar.

The process of Co-Cr-Mo alloy production is shown in Figure 1. In the first step, the raw materials and moulds are prepared. A mould is prepared by a method of meltable models, mainly used in production of small weight casting of a very smooth surface. A model made of material with a low melting point, a kind of wax (paraffin, stearine), is gradually covered by layers of mixture, each with different granulometry, until the mould i.e. shell with $5-7 \mathrm{~mm}$ thick walls is obtained. When the model melts out leaving a cavity, corresponding strictly to the shape of a desired model, the shell can be used as a precise casting mould.

Previous degassing is required for cobalt and chromium. They are annealed at $1000^{\circ}-1100^{\circ} \mathrm{C}$ respectively, at pressure of $0.18-0.23$ mbar. Prepared in such a way, these metals are being gradually charged into a high-aluminous corundum crucible of the induction vacuum furnace. This material is resistant to a corrosion of a metal charge and dross, as well as to an abrasive effect of the charge.

Melting and casting may be performed under vacuum or in argon atmosphere. If argon is used, it has to be of extremely purity $(99,99 \%)$, while the pressure in the furnace receptor should be kept below $0.10 \mathrm{Mbar}$.

The mould was preheated to the temperature of $1050^{\circ} \mathrm{C} \pm 15^{\circ} \mathrm{C}$. The casting temperature was $1530^{\circ}-1540^{\circ} \mathrm{C}$. The shell mould material and wall thickness enabled the cooling control, as well as the grain size and shape control, influencing the mechanical characteristics. Monitoring the pressure change, it can be observed the beginning and the end of secondary degassing, i.e. the beginning and the end of melting and casting in a closed vacuum chamber.

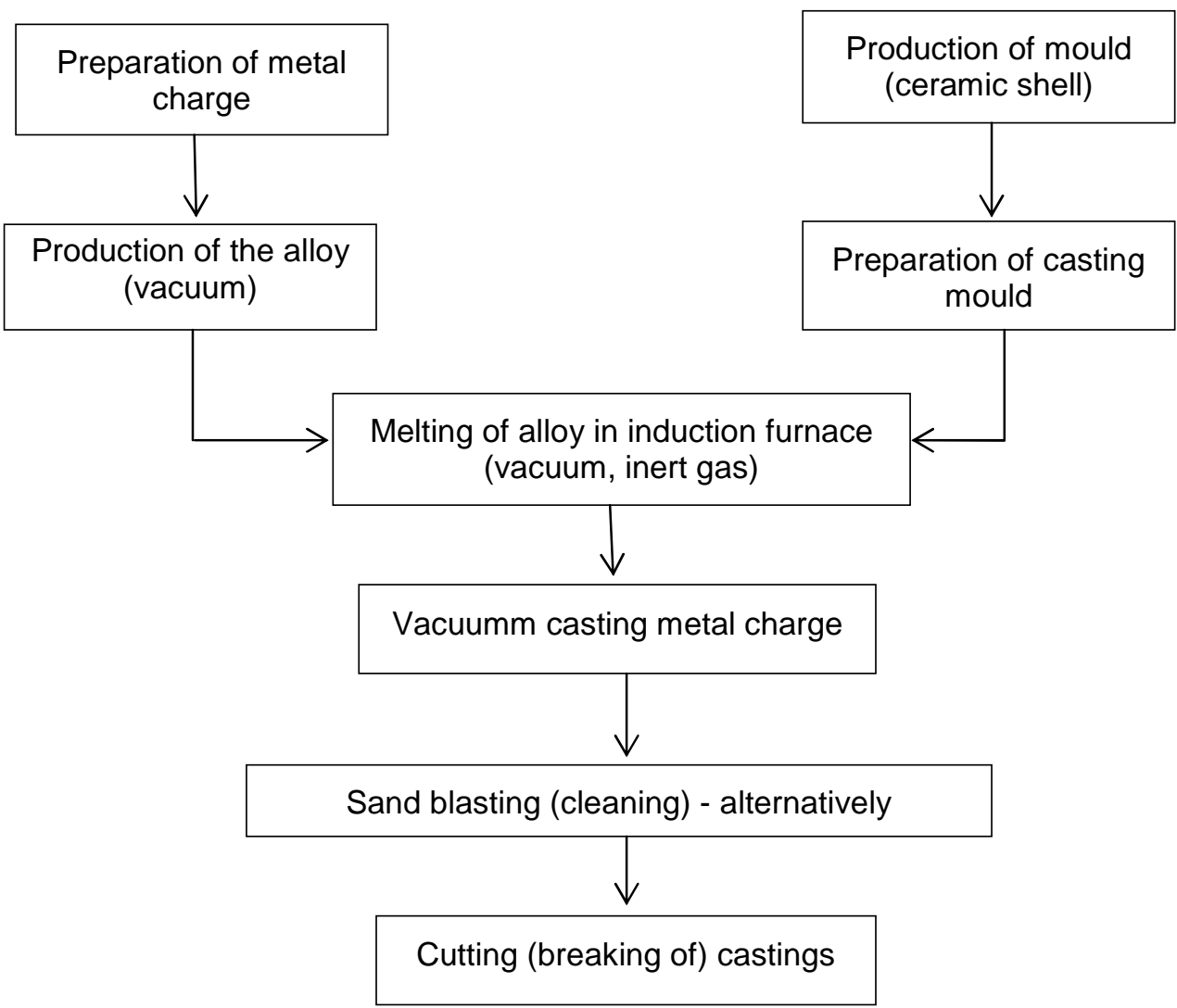

Figure 1 - The experimental scheme 
Alloy is casted in a form of tablets of $5.5 \mathrm{~g}$ and $9.5 \mathrm{~g}$. Due to the vacuum precise casting process characteristics, the obtained samples are with precise dimensions and good surface, without the need for additional sandblasting.

\section{RESULTS AND DISCUSSION}

According to the described experimental process, the samples were obtained in a form of tablets.

The chemical analysis of produced alloy is presented in the Table 1.

The obtained alloy is according to ASTM standard (ASTM F75) for casting alloys for surgical implants. The nickel content should be below 1

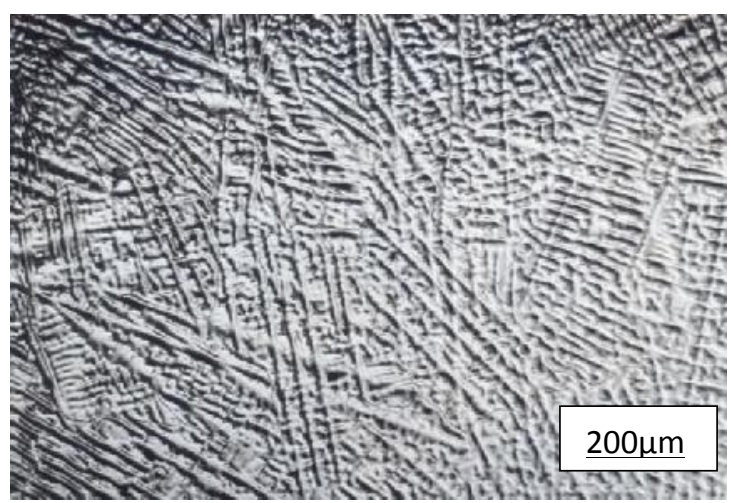

Figure 2a Microscope magnification 50x

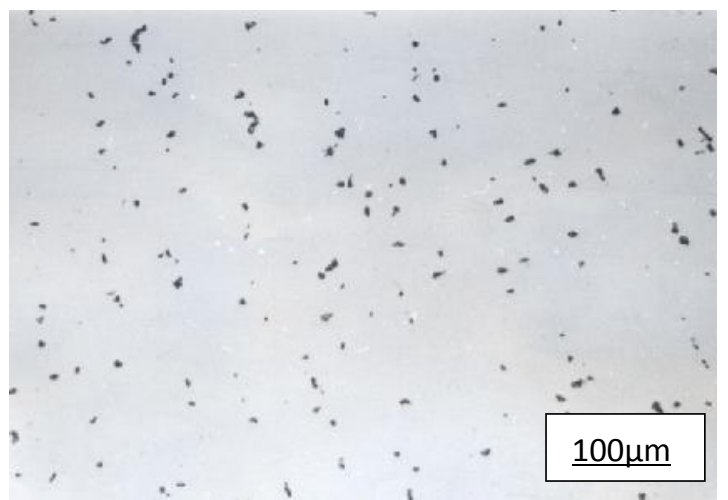

Figure 2c-Microscope magnification 100x mass\%, and there is no $\mathrm{Ni}$ in these precisely prepared and vacuum melted raw materials. This is mainly due to ion release into the body fluid.

Table 1 - The produced alloy composition

\begin{tabular}{|l|c|c|c|c|c|c|c|}
\hline Element & Co & Cr & Mo & Mn & Fe & Si & C \\
\hline $\begin{array}{l}\text { Content } \\
\%\end{array}$ & 65.7 & 27.0 & 5.0 & 0.75 & 0.50 & 0.75 & 0.30 \\
\hline
\end{tabular}

The optical microscopy photographs of the ascast structure of Co-Cr-Mo samples are presented in Figs. 2a-2d. Figure 2a represents the general structure under small magnification, while grains within the structure are visible in Fig. $2 b$.

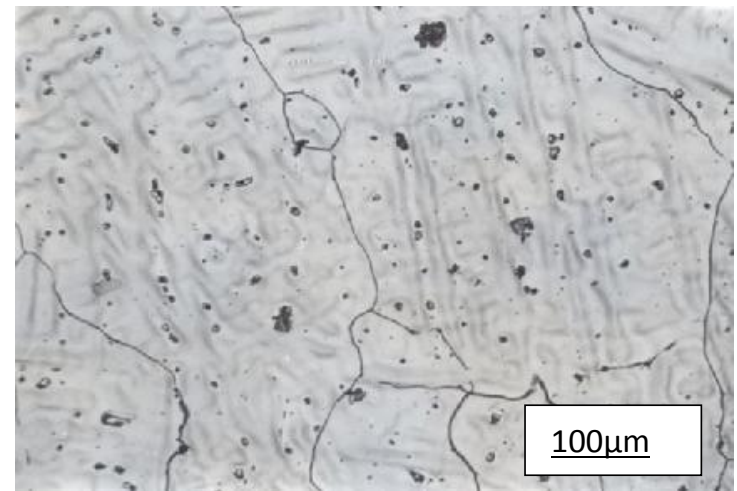

Figure $2 b$ - Microscope magnification $100 x$

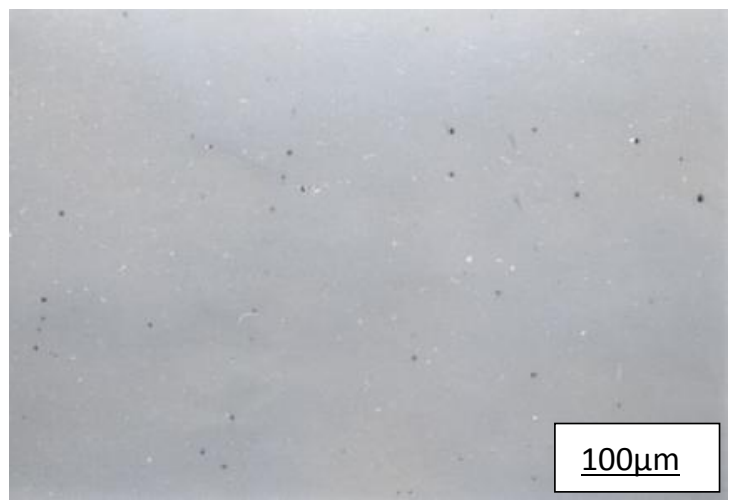

Figure 2d - Microscope magnification 100x

Figure 2a-2d - The as-cast structure of the Co-Cr-Mo sample

The fine carbides with homogenous distribution can be observed in Fig. 1c. The alloy microstructure consists of a cobalt matrix with finely dispersed carbides, usually chromium and molybdenum carbides. They are globular and when homogeneously distributed, they improve mechanical characteristics of an alloy. The $\mathrm{Cr}_{7} \mathrm{C}_{3}$ carbides are eutectic with the Co-solid solution, while the $\mathrm{Cr}_{23} \mathrm{C}_{6}$ carbides are a precipitate in the form of fishbone shape [9].

The rare, globular in shape and also finely distributed nonmetallic inclusions are shown in Fig.1d. The quality of technological process and good conducted experimental procedure reveals in such shape and distribution, which contribute the good castings quality and electrochemical stability, i.e. the corrosion behavior [2-4].

The investigations of metal ions dissolution into the simulated body fluid (SBF) reveal that all present metals were registered dissolved in SBF [9]. They reported that even trace elements in an alloy could not be negligible from the viewpoint of metal ion release. Here comes out the importance of careful alloy preparation. 
Rodrigues et al. [2] reported that greater chemical and microstructural homogeneity and hence better corrosion resistance are due to lower carbon content. Since there are Co-Cr-Mo alloys with carbon content the order of magnitude lower than ours, the attention should be paid to nonmetallic inclusions and carbon particles distribution.

The Co-Cr-Mo alloys in as-cast condition consist of the $\mathrm{Y}$-phase (face centered cubic - f.c.c.) and the $\varepsilon$-phase (hexagonal close packing - h.c.p.). The transformation from $y$ to $\varepsilon$ proceeds during cooling. The $\sigma$-phase can be observed on grain boundaries and its amount increases with ageing time. Concerning the Co-Cr-Mo alloys, their properties of the alloys significantly depend on the ratio of these phases. Elongation of similar alloy, namely Co$29 \mathrm{Cr}-6 \mathrm{Mo}$ alloy, increases with fraction increase of the $y$ phase [6]. On the other hand, the quantity of released metal ion tends to decrease with increasing the $\varepsilon$-phase. Besides this, wear resistance of Co-Cr-Mo alloys consisting of the $\varepsilon$-phase are promising for metal-to-metal usage. Generally, the alloy consisting of the $Y$ phase is favorable for plastic forming, while the alloy consisting of the $\varepsilon$ phase is capable for the corrosion or wear resistance.

\section{CONCLUSIONS}

- The raw material were carefully selected and prepared by grinding, with afterwards degassing.

- The alloy was obtained in the vacuum, using the vacuum induction melting method.

- Simultaneously, the mould shell is prepared to obtain the net casting shape and dimensions, without the need for additional machining.

- The mould was preheated to the temperature of $1050^{\circ} \mathrm{C} \pm 15^{\circ} \mathrm{C}$. The casting temperature was $1530^{\circ}-1540^{\circ} \mathrm{C}$.

- Melting and casting was conducted under the vacuum of 0.04 mbar.
- The alloy microstructure consists of a cobalt matrix with finely dispersed carbides, usually chromium and molybdenum carbides. They are globular and because of homogenous distribution, they improve mechanical characteristics of an alloy.

\section{Acknowledgement}

The authors wish to acknowledge the financial support from the Ministry of Education, Science and Technological Development of the Republic of Serbia through the project TR 34002.

\section{LITERATURE}

[1] B. Li, A. Mukasyan, A. Varma (2003) Combustion synthesis of CoCrMo orthopedic implant alloys: microstructure and properties, Materials Research Innovations 7, 4, 245-252.

[2] W.C. Rodrigues, et al. (2010) Powder metallurgical processing of Co-28\%Cr-6\%Mo for dental implants, Powder Technol. doi:10.1016/j.powtec.2010.09.024

[3] P.E. Sinnett-Jones, J.A. Wharton, R.J.K. Wood, (2005) Wear 259, 898

[4] P. Sury, M. Semlitsch (1978) Journal of Biomedical Materials Research 12, 723.

[5] T.M. Devine, J. Wulff (1975) Journal of Biomedical Materials Research 9, 151.

[6] Shingo Kurosu, Naoyuki Nomura, Akihiko Chiba (2006) Effect of Sigma Phase in Co-29Cr-6Mo Alloy on Corrosion Behavior in Saline Solution, Materials Transactions, Vol. 47, 8, 1961-1964.

[7] T. M. Devine, J. Wulff (1975) Cast vs Wrought Cobalt-Chromium Surgical Implant Alloys, J.Biomed. Mater.Res. 9 (1975) 151-167.

[8] R. Liu, S.Q. Xi, S. Kapoor, X.J. Wu (2010) Effects of chemical composition on solidification, microstructure and hardness of $\mathrm{Co}-\mathrm{Cr}-\mathrm{W}-\mathrm{Ni}$ and $\mathrm{Co}$ Cr-Mo-Ni alloy systems, IJRRAS 5, 2, 110-122.

[9] N. Maruyama, H. Kawasaki, A. Yamamoto, S. Hiromoto, H. Imai, T. Hanawa (2005) Friction-Wear Properties of Nickel-Free Co-Cr-Mo Alloy in a Simulated Body Fluid, Materials Transactions, Vol. 46,7, 1588-1592.

\section{IZVOD}

\section{LEGURE Co-Mo-Cr ZA PRIMENU U STOMATOLOGIJI DOBIJENE PRECIZNIM LIVENJEM U VAKUUMU}

Za proizvodnju odlivaka od kojih se izrađuju zubni implantati, ortodontski aparati i pomoćni materijali koristi se više legura Co-Cr-Mo, različitog sastava. Ovde je reč o leguri, koja pored odsustva nikla, svoje biokompatibilnosti i otpornosti na koroziju, ima odlične mehaničke karakteristike, kao što su tvrdoća, zatezna čvrstoća i žilavost.

Predstavljena je tehnologija pripreme sirovina, kao i izrada same legure u vidu uzoraka-tabletica od kojih se izradjuju zubni implantati, tehnologijom preciznog livenja u vakuumu, korišćenjem metode topivih modela. Osim eksperimantalnih parametara, praćen je hemijski sastav od polaznih sirovina do gotove legure. Prikazana je mikrostruktura uzoraka u livenom stanju.

Ključne reči: Co-Cr-Mo legura, dentalni implantati, livenje u vakuumu

Originalni naučni rad

Rad primljen: 13. 12. 2014.

Rad prihvaćen: 21. 02. 2015. 